\title{
The Economy of the Russian Arctic: State and Specifics of Development
}

\author{
Vladimir Plotnikov \\ St. Petersburg State University of Economics, \\ Department of General Economic Theory \& History of \\ Economic Thought \\ St. Petersburg, Russia \\ plotnikov_2000@mail.ru
}

\author{
Maria Kutepova \\ St. Petersburg State University of Economics, \\ Department of General Economic Theory \& History of \\ Economic Thought \\ St. Petersburg, Russia \\ m180794@mail.ru
}

\author{
Olga Sushko \\ Northern (Arctic) Federal University named after M.V. Lomonosov, \\ Department of Economics and Entrepreneurship, Arkhangelsk, Russia \\ o.shushko@narfu.ru
}

\begin{abstract}
The Arctic zone of the Russian Federation is a unique in its characteristics macroregion. The analysis of its specifics shows that it is able to become a driver in economics growth and socioeconomic development of the country in the midterm. The key role in the economic development of the Russian Arctic will be played by the implementation of exportoriented projects on oil and gas recovery. A successful realization of this scenario of development faces a number of restrictions of judicial, economic, natural and climatic, ecological, and technological type, etc. These negative factors should be taken into account for economic policy implementation in the given macroregion.
\end{abstract}

Keywords - Arctic Zone of Russia, socioeconomic development, spatial economics, extractive industry

\section{INTRODUCTION}

Nowadays we can observe gradual depletion of resources available for development. It causes the intensification of the struggle for an access to them between countries and major corporations. This fact is one of the main reasons for increasing interest in development and use of resources of Arctic [1 - 4].

The Russian Federation is one of the Arctic countries. It possesses vast northern territories and water areas of polar seas. At the same time the Arctic Zone of the country remains very poorly developed. The opportunities to involve the resources of the Russian Arctic in the economic turnover are currently used to a small extent. It is subject to a number of factors, both objective and subjective, which were formed at the previous stages of development of the country.
Russian scientists and specialists consider Arctic to be one of the potential drivers of the economic growth of Russia. This growth, in the authors' opinion, can be provided, first of all, by natural resources development (firstly, hydrocarbon) and the development of northern shipping industry [5]. Besides, the intensification of global instability and growth in intensity of conflicts in the world increase the strategic role of the Arctic region in providing national security of Russia. It requires the activation of processes of natural resources development in the Arctic Zone of Russia.

The aim of this study is the analysis of economic development performance of the Arctic Zone of the Russian Federation in view of its specific features, identification of prospects and development trends of this macroregion.

\section{MATERIALS AND METHODS}

In this study we used the methods of system analysis, factor analysis, case study, Delphi approach, comparativehistorical and logical approach to study the chosen topic. The methodology basis of the author's analysis were dialectical and systemic approaches examining the phenomena and processes under study as closely interrelated, and the development process as a continuous process of resolution of the current conflicts and forming new ones which are subject to resolution at the following stages of development.

The values of official regional, national, and international statistics and the review of works on Arctic published in Russian in the last fifteen years were used as basic data [6]. Their content analysis carried out by M. Kutepova let us ascertain that economic problematics is not reflected enough in a scientifical literature despite its importance (Fig. 1). 
Naturally, the issues of economic development of the Arctic regions are inextricably linked to the development of medicine and healthcare, transportation system, ecology, and others. Nevertheless, as it follows from Fig. 1, in reality regional economic conditions remain understudied.

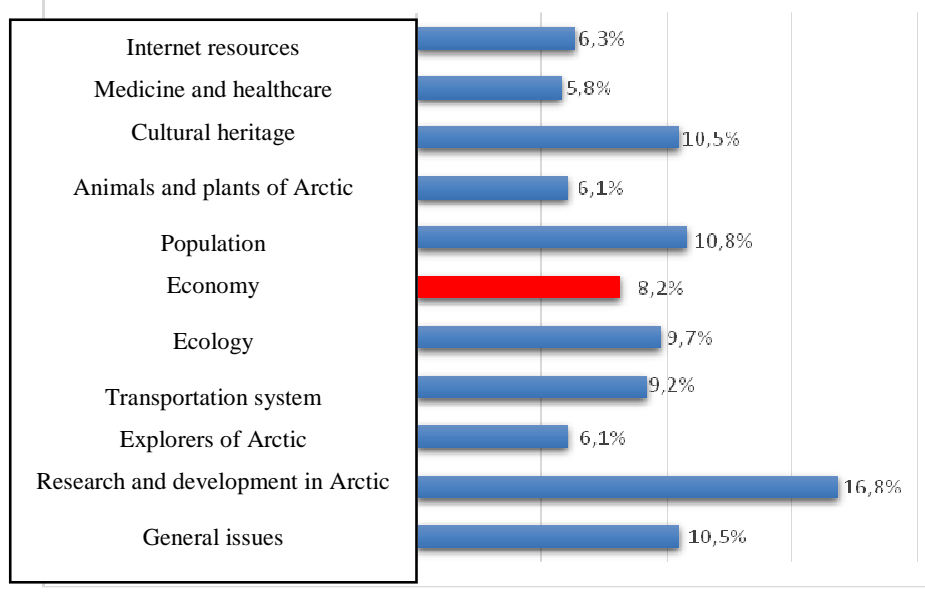

Fig. 1. Structure of publications in Russian on Arctic (1991-2016). Prepared by $\mathrm{M}$. Kutepova on the basis of [6].

\section{RESULTS AND DISCUSSION}

\section{A. General characteristics of economic development of the Arctic Zone of the Russian Federation}

Quite a powerful industrial base is created in the Russian Arctic. The extent of economic activity in this macroregion of Russia considerably exceeds figures of other subarctic countries. It is estimated that $12-15 \%$ of the country's GDP is formed in the Arctic Zone, which provides about a quarter of the export [7].

Despite the insignificant share of the Arctic Zone in the Russian population size, (on January 1, according to Federal State Statistics Service, a little more than 2.37 million of people lived there, which is less than $2 \%$ of permanent population of the country) and involved in economics activity, it provides more than $5 \%$ of the total GRP of Russian regions.

Enterprises of this macroregion are mainly involved in extraction and primary processing of minerals. The share of value added of resources industries and enterprises in GRP exceeds 50\%. For reference, it is no more than $15 \%$ in Greenland, Norway, Sweden, Finland, Iceland; and about $30 \%$ in Alaska and Canada. Two-thirds of the total wealth of Arctic as an international macroregion is created in the Arctic Zone of Russia [7, c. 13].

The specific character of contemporary development of Arctic macroregion of Russia is in great measure the result of historical features of its economic development during the period of the USSR. It was to, a large extent, determined by geopolitical rather than economic considerations [8, p. 509]. Economic development of Russian (Soviet) Arctic and formation of its spatial economic structure started under the strong influence of the politico-military factor, so that the economy of this macroregion developed as a part of a unified national economic complex of the country.

Harsh natural and climatic conditions formed a local type of economic development. Economic activity is basically localized in locations of extractive enterprises and defense facilities, along transportation lines, at the shore of polar seas and lower reaches of rivers flowing into them. The economic activity and livelihood of the population strongly depend on the "Nothern supply"

The "Nothern supply" is a seasonal bulk delivery of different goods, first of all, food and fuel, in a warm period of the year, when river and maritime navigation are possible. Due to this economic development in the Arctic Zone of Russian Federation is closely related to development and exploitation of the Northern Sea Route.

In terms of international trade, the Northern Sea Route serves as a route connecting Western Europe and Eastern Asia whereas in terms of development of Russian Arctic Zone, it performs important functions of its sustainability.

Economic structure of the majority of Arctic territories is diversified feebly and has a sector-specific character with dominance of extraction industry. Further economic development of the Arctic Zone of Russia is held by the lack of development of production infrastructure (primarily, transport) and social infrastructure, which stimulates out migration (Table 1) and complicates the general demographic and socioeconomic situation in this macroregion.

Extreme weather conditions, limited transport accessibility, lack of development of energy infrastructure are the drivers of population support and development of economic activity in Arctic. For example, it is estimated that a share of transport expenses in the cost of the end-product can reach $60 \%$ (the national average is about $10 \%$ ).

Despite the existing difficulties, the Arctic Zone has a considerable potential for development. In general the country has accumulated a unique experience of economic activity and efficient management practice in this specific macroregion. The above-mentioned circumstances are, in fact, national competitive strengths which need to be used more actively. In this context, the following features of the given macroregion should be taken into account:

- Unique natural and climatic conditions.

- Low density of population, a local type of economic activity in the region.

- High capital-output ratio and dependence on supply of fuel, food, manufacturing resources and basic necessities.

- Low ecosystem stability to human impact, fragile and vulnerable natural balance of ecosystems. 
TABLE I. POSITIVE MIGRATION BALANCE RATIO OF THE ARCTIC ZONE OF THE RUSSIAN FEDERATION, \%o

\begin{tabular}{|l|r|r|}
\hline \multicolumn{1}{|c|}{ Region } & $\mathbf{2 0 1 5}$ & $\mathbf{2 0 1 6}$ \\
\hline Total, including: & $-9,6$ & $-5,9$ \\
\hline Republic of Komi & $-22,0$ & $-18,0$ \\
\hline Republic of Sakha (Yakutia) & $-9,3$ & $-3,8$ \\
\hline Krasnoyarsk Region & $-6,8$ & $-8,8$ \\
\hline $\begin{array}{l}\text { the Arkhangelsk Region without Nenets } \\
\text { Autonomous Area }\end{array}$ & $-3,6$ & $-2,8$ \\
\hline Nenets Autonomous Area & 2,3 & $-7,3$ \\
\hline Murmansk Region & $-5,7$ & $-5,7$ \\
\hline Yamalo-Nenets Autonomous Area & $-237,8$ & $-69,8$ \\
\hline Chukot Autonomous Area & $-1,1$ & $-1,0$ \\
\hline
\end{tabular}

Source: Federal State Statistics Service.

- Lack of infrastructural development. Fragmentary character of current infrastructure.

- Richest mineral resource potential including considerable oil and gas reserves.

\section{B. Development prospects of extractive industry as the key industry of economics of the Arctic Zone of the Russian Federation}

Considerable reserves and undiscovered potential resources of copper-nickel ores, tin, platinoids, agricultural chemical ores, rare metals and rare-earth elements, gold, diamonds, tungsten, mercury, ferrous metals, optical raw materials, ornamental stones and other natural raw material are localized in Arctic. Besides, in the Arctic Zone of Russian Federation there is a number of large coal-basins such as Pechora, Sosvin-Salekhard, Taimyrsky, Tunguska, Lena, and Beringovsky basins.

It is estimated that comparing to overall extraction in Russia, $100 \%$ of antimony, apatite, phlogopite, vermiculite, barite, rare metals, $98 \%$ of diamonds, over $95 \%$ of platinum group metals, over $90 \%$ of nickel and cobalt, $60 \%$ of copper are extracted in the Arctic Zone [9]. However, the main subindustry of extractive industry in the macroregion is oil and gas recovery.

In the Arctic Zone the greatest share is held by gas storage. About $80 \%$ of Russian gas is recovered in Arctic and considerable resources of it are found there. It is estimated [10] that Russian Arctic territories and continental shelf contain the largest in Arctic part of oil and natural gas (Fig. 2 and 3 ).

Mineral assets in the onshore area of the macroregion are rather proved and are developed actively. Arctic continental shelf is less developed. It is a prospective zone for development. Hydrocarbon deposits in shelf offshore areas of the polar seas are strategic reserves for Russian oil and gas sector development.

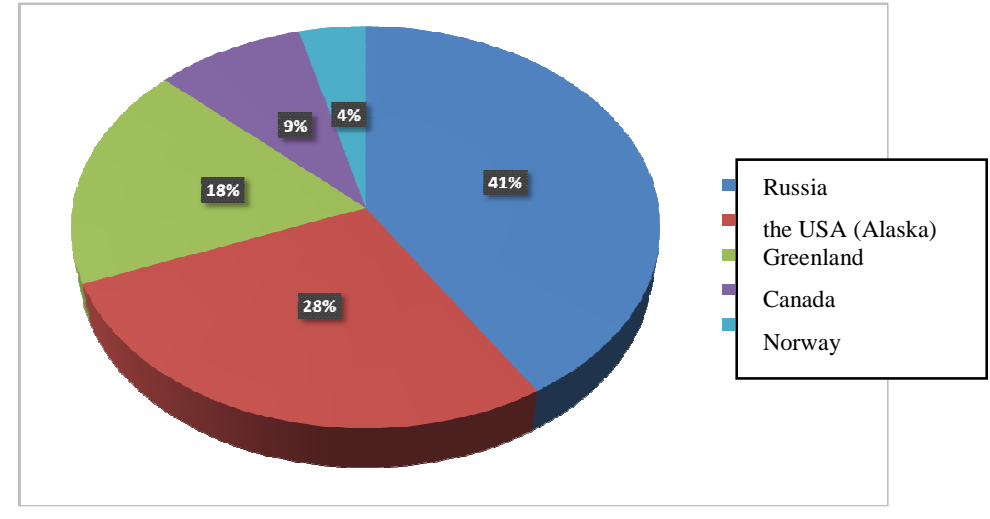

Fig. 2. Distribution of prospective reserves of oil among Arctic countries. Prepared on the basis of [10].

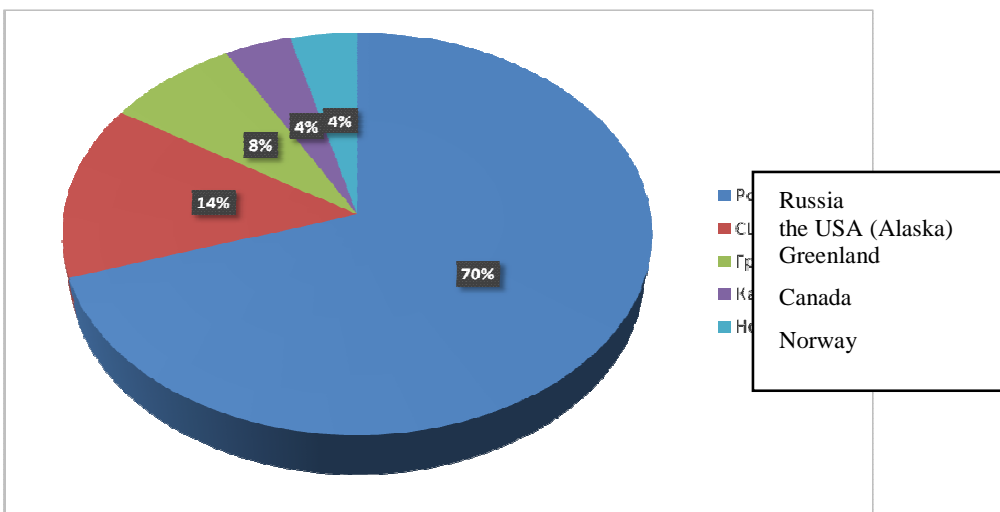

Fig. 3. Distribution of prospective reserves of natural gas among Arctic countries. Prepared on the basis of [10].

The greatest share of hydrocarbon resources (about 70\%) is attributed to Western Arctic seas - the Barents Sea and the Kara Sea. Initial total geological resources in the Barents Sea are estimated to be 34.9 billion tons of oil equivalent and in the Kara Sea (including gulfs and bays) to be 48.9 billion tons. There are 5.0 billion tons of oil equivalent of recoverable hydrocarbons in the Barents Sea, and 7.2 billion tons in the Kara Sea [7].

In Arctic seas such as Barents Sea, Pechora Sea, and Kara Sea (including gulfs and bays) 25 deposits of oil and gas are discovered (the Shtokman field, Leningradskoye and Rusanovskoye gas condensate fields, Yurkharovskoye oil condensate field, Kamennomysskoye-Sea gas field, Dolginskoye and Prirazlomnoye oil fields and others). The Shtokman field is the largest in the world. It contains about 4 trillion cubic meters of gas [7].

The key role in development of gas recovery is played by Yamalo-Nenets Autonomous Area. It is the largest gas producing region of Russia. 85\% of overall Russian gas extraction and $20 \%$ of world production of natural gas are localized in this area of the Arctic Zone. 234 hydrocarbon deposits are discovered here, 66 of which are being commercially operated [11].

Extracted hydrocarbon resources of the continental shelf in the Arctic Zone of the Russian Federation comprise over 83 
billion tons of oil equivalent, including about 13 billion tons of oil and gas condensate and over 70 trillion cubic meters of natural gas. About $85 \%$ out of almost 100 billion tons of oil equivalent of extracted hydrocarbon resources from the total Russian shelf are concentrated in Arctic [11].

By 2025 , in favorable conditions, the continental shelf will have been able to provide up to $25 \%$ of total Russian oil recovery and up to $30 \%$ of gas recovery [12]. However, this development scenario faces a number of impending factors, among which the key role is played by anti-Russian sanctions imposed by the USA, the EU, and a number of other countries as well as by unstable prices on oil and natural gas.

The first factor is a result of technological limitations which are represented by a ban to supply in Russia the equipment for oil and gas recovery from the Arctic shelf. The equipment of Russian own production is not created yet. The second factor determines changes in payoff periods and profitability levels of shelf projects and is a source of risks restraining their implementation $[5,13,14]$.

Analysis has shown that large reserves of mineral resources is one of the main competitive strengths of the Arctic Zone of the Russian Federation and the main factor of its further development and economic growth. In the mid-term we will be able to speak not only about the onshore production but also about the offshore production on the Arctic shelf. Potential resources of the Russian Arctic not only favor economic and social development of this macroregion but also consolidate competitive positions of Russia in the world.

\section{Factors inpacting the development of economy of the Russian Arctic}

Apart from the above mentioned factors, there is a range of additional ones that impact the development of economic activity in Arctic. We will conduct a review of them.

Along with mineral reserves, the Russian Arctic has considerable reserves of marine bioresources. The important difference from mineral reserves lies in their renewable character. In the long-term their proper use can provide a basis for sustainable economic activity in the macroregion. More than a third of fish and seafood caught in Russia and about $20 \%$ of canned fish are produced in the Arctic Zone. And this potential has preconditions for development.

A distinctive feature of Russian Arctic which developed under the influence of historical and natural and climatic factors is a model of extensive economic growth. Theoretically, the resource wealth of the macroregion permits to use this model further on. At the same time, it is pointless to build volumes of extraction, which leads to exhaustion and depletion, and export exhaustible low processed resources.

Therefore, the economy of the macroregion needs to be intensified with implementation of new technologies that will permit to produce and export more highly processed products. Taking into account the northern place distinctiveness, these measures cannot be taken without an active government support. As a result, there is a need in increasing government intervention into the economy of the macroregion.
High resource dependence leads to regional economic differentiation and single-industry orientation of the Arctic Zone constituent entities. It negatively affects their resilience to external and internal shocks. The analysis of the main levels of socioeconomic development of the Arctic regions has shown that they are greatly differentiated and oppositely diverged from similar average Russian parameters.

Therefore, it is not advisable to use in these regions the typical standardised tools of the economic policy and methods of state regulation of the regional development. There is a need in a fuller and more careful analysis with consideration for specific features of the constituent entities of the Federation.

Low density of population and a local type of economic development require the implementation of economic projects using the rotational team method, which should be taken into account while developing social and transport infrastructure as well as reconciliation of new projects with interests of the indigenous population of the North whose rights are protected by Russian legislation.

There is a considerable interest of foreign investors and international community on the whole in participation in economic development of the Russian Arctic Zone. For example, the Northern Sea Route has been open for international navigation since 1991. Companies from different countries show interest in shelf project development, etc.

However, taking into account the political pressure on Russia and imposed on it economic sanctions by a group of unfriendly countries, international projects in Arctic require not only profound economic but also judicial elaboration as well as a thorough evaluation of political risks.

\section{CONCLUSION}

The development of the Arctic Zone of the Russian Federation is one of the Russian economic policy priorities. The main competitive strength of the macroregion is its richness in natural resources, first of all, oil and gas. Thanks to their presence, the constituent entities of the Russian Federation situated in this zone play a leading role not only in Russia but also around the world. At the same time, the economy based on extraction and export of hydrocarbons is not stable. There is a need in its diversification and intensification. Taking into account the specific features of the macroregion, the above-mentioned structural changes cannot be introduced relying on self-regulating market. To solve a range of regional development problems an active intervention in economic and social government processes is required. 


\section{Acknowledgment}

This paper is an output of the science project of the government task of Ministry of education and science of the Russian Federation \# 26.3546.2017/PCH "Development fundamentals of analysis and prediction of structural and dynamic parameters of the regional economy are based on the integration of the Russian and world experience of management of territorial development and modern scientific doctrines".

\section{References}

[1] P.E. Solli, E. Wilson Rowe, and W. Yennie Lindgren. "Coming into the cold: Asia's Arctic interests”, Polar Geography, vol. 36(4), pp. 253-270, 2013.

[2] O.R. Young. "Arctic tipping points: Governance in turbulent times", Ambio, vol. 41(1), pp. 75-84, 2012.

[3] T. Pedersen "Debates over the role of the arctic council", Ocean Development and International Law, vol. 43(2), pp. 146-156, 2012.

[4] R.E. Doel, U. Wråkberg, and S. Zeller. "Science, Environment, and the New Arctic", Journal of Historical Geography, vol. 44, pp. 2-14, 2014.

[5] V.A. Plotnikov, and M.V. Kutepova. "Management of economic security of oil companies (based on the example of assessing and reducing the risks of implementing projects to develop oil fields in the Arctic region of Russia) [Upravlenie ekonomicheskoi bezopasnost'yu neftyanykh kompanii (na primere otsenki i snizheniya riskov realizatsii proektov osvoeniya neftyanykh mestorozhdenii Arkticheskogo regiona Rossii)]", Proceedings of the Southwestern State University. Series: The Economy. Sociology. Management [Izvestiya Yugo-Zapadnogo gosudarstvennogo universiteta. Seriya: Ekonomika. Sotsiologiya. Menedzhment], vol. 7, Iss. 1 (22), pp. 39-49, 2017.

[6] O.V. Kokovkina. " The study of the Russian Arctic (bibliography 19912016) [Izuchenie rossiiskoi Arktiki (bibliografiya 1991-2016)]", available http://www.prometeus.nsc.ru/archives/exhibit2/rusarc.ssi\#m8.
[7] "Draft Strategy for the Development of the Arctic Zone of the Russian Federation and Ensuring National Security for the Period to 2020 [Proekt Strategii razvitiya Arkticheskoi zony Rossiiskoi Federatsii i obespecheniya natsional'noi bezopasnosti na period do 2020 goda]“, available at: http://narfu.ru/development_program/Stategy_arctic.pdf.

[8] A.N. Piliasov. "And the last will be the first: The northern periphery on the way to the knowledge economy [I poslednie stanut pervymi: Severnaya periferiya na puti k ekonomike znaniya]", Moscow, Librokom Publishing, 2009, 544 p.

[9] "Mineral resources of the Russian Arctic: state, prospects, directions of research [Mineral'no-syr'evye resursy Rossiiskoi Arktiki: sostoyanie, perspektivy, napravleniya issledovanii]", St. Petersburg, Sciense Publishing, 2007, $766 \mathrm{p}$.

[10] 10. L. Lindholt, and S. Glomsrød. "The Role of the Arctic in Future Global Petroleum Supply", Statistics Norway, Research Department. Discussion Papers № 645, February 2011.

[11] "Arctic Deposits [Mestorozhdeniya Arktiki]", available at: http://www.arctic-info.ru/Encyclopedia/Rubric/Месторождения.

[12] Strategic Challenges and Economic Factors of Marine Policy in the Russian Arctic [Strategicheskie vyzovy i ekonomicheskie faktory morskoi politiki v rossiiskoi Arktike]", Apatity, Kola Science Center of the Russian Academy of Sciences, 2011, 199 p.

[13] Tsatsulin, A.N., Babkin, A.V., Babkina, N.I. Analysis of the structural components and measurement of the effects of cost inflation in the industry with the help of the index method // Proceedings of the 28th International Business Information Management Association Conference - Vision 2020: Innovation Management, Development Sustainability, and Competitive Economic Growth, 2016. C. 1559-1573.

[14] Babkin, A.V., Karlina, E.P., Epifanova, N.Sh. Neural networks as a tool of forecasting of socioeconomic systems strategic development // Proceedings of the 28th International Business Information Management Association Conference - Vision 2020: Innovation Management, Development Sustainability, and Competitive Economic Growth, 2016. C. $11-17$ 